\title{
The effect of seismic base isolation on structural response of a 12- story hotel building in Padang, Indonesia
}

\author{
Fauzan $^{1}$, Afdhalul Ihsan ${ }^{1}$, Mutia Putri Monika ${ }^{1}$, and Zev Al Jauhari ${ }^{2}$ \\ ${ }^{1}$ Civil Engineering Department, Andalas University, 25163 Limau Manis, Padang, Indonesia \\ ${ }^{2}$ Civil Engineering Department, Bengkalis State Polytechnic, 28711 Sungai Alam, Bengkalis, Indonesia
}

\begin{abstract}
The amount of potential investment in Padang City, Indonesia since 2017 attracted many investors to contribute to the city. One of the investments is a 12-story hotel that will be constructed in By Pass Street of the city. The hotel is located in a high seismic zone area, so the seismic base isolation has been proposed to be used in the hotel building. The main aim of using a seismic base isolation device is to reduce the inertia forces introduced in the structure due to earthquakes by shifting the fundamental period of the structure out of dangerous resonance range and concentration of the deformation demand at the isolation system. An analytical study on the Reinforced Concrete (RC) hotel building with and without rubber bearing $(\mathrm{RB})$ base isolation is carried out using the response spectrum and time history analysis methods. The results show that internal forces and inter-story drift of the building with high damping rubber bearing (HDRB) are lower than that of the fixed base with a remarkable margin. From this study, it is recommended to use the HDRB base isolation for medium and high rise buildings with soft soil in Padang City, Indonesia.
\end{abstract}

\section{Introduction}

The big amount of potential investment in Padang City, the capital city of West Sumatra, made the city win an investment-worthy city award in the Indonesia Attractiveness Award in 2017. As a consequence of the high tourism possibility and hotel occupancy rates in Padang City, an increase of 11.44 points from $52.36 \%$ in February 2016 to $64.04 \%$ in March 2017, caused a lot of new hotels were constructed in Padang City in last two years.

One of the oncoming hotels is Melia International (MI) hotel that was planned to build a five-star hotel located at $\mathrm{km}$. 16 of by-pass road area, targeted tourists and cross-province road users. Following the limited land, Melia International Hotel will be built vertically with 12 floors with a semi-basement for parking area, the $10^{\text {th }}$ floor for hotel functions and the roof floor as a helipad base. However, the construction of the hotel will not be easy because the area is susceptible to earthquake disasters. Also, the land of this area is categorized as soft soil (SE) which has the potential for magnification of earthquake waves $[1,2]$.

This is not tolerable for buildings whose contents are more costly and valuable than the buildings themselves. Therefore, a special technique to minimize the risks, the base isolation technique is increasingly being adopted. Base isolation is to prevent the superstructure of the building from absorbing the earthquake energy [3, 4]. A structure with base isolator has been supported by isolation elements (such as rubber bearings or sliders), which are typically installed between the building structure and its foundation [5]. During an earthquake, the fixed base structure without seismic isolation is subjected to substantial story drifts, which may lead to damage or even collapse of the building $[6,7]$.

Therefore, this study, the Moment Resisting Frames with Shear Wall (Dual System) structural system building has been modeled and analyzed for the hotel building using the current earthquake standard code (SNI 1726:2012) and the 2017 earthquake hazard map [8]. The analysis results in terms of structural elements internal forces, story displacement, and inter-story drift were obtained from spectrum response and time history analysis for both fixed base and base-isolated buildings. Finally, it was of interest to check the difference between the responses of a fixed-base building frame and the isolated-base building frame under seismic loading.

\section{Design and analysis of the building}

\subsection{Preliminary design}

The design of structures as thought courses tends to consist of guessing the size of members required in a given structure and analyzing them. The structural members should be designed for optimum use of its materials i.e. steel and concrete [9]. Similarly, at a global level of the structure, the design should be such that, each member should be used optimally. Initial dimensions (preliminary design) of the structural element were detailed by following the steps and standards in SNI 2847:2013 [10].

\footnotetext{
* Corresponding author: fauzan@eng.unand.ac.id
} 


\subsubsection{The beam}

The dimensions of the beam elements were designed according to the SNI 2847:2013, as shown in Table 1.

\subsubsection{The slab}

The dimensions of the building slabs were designed to be $120 \mathrm{~mm}$ for the interior floor, $100 \mathrm{~cm}$ for concrete floor deck, and $250 \mathrm{~mm}$ for the helipad.

Table 1. The cross-sectional dimensions of the beams.

\begin{tabular}{|c|c|c|c|}
\hline \multicolumn{2}{|c|}{ Primary Beam } & \multicolumn{2}{c|}{ Secondary Beam } \\
\hline Span (m) & $\begin{array}{c}\mathbf{h} \times \mathbf{b}_{\mathbf{w}} \\
(\mathbf{m m})\end{array}$ & Span (m) & $\begin{array}{c}\mathbf{h} \times \mathbf{b}_{\mathbf{w}} \\
(\mathbf{m m})\end{array}$ \\
\hline 8 & $580 \times 300$ & 8 & $540 \times 270$ \\
\hline 7 & $560 \times 280$ & 7 & $480 \times 260$ \\
\hline 6 & $550 \times 280$ & 6 & $400 \times 260$ \\
\hline 5.5 & $550 \times 280$ & 5.5 & $400 \times 260$ \\
\hline 5 & $400 \times 260$ & 5 & $380 \times 250$ \\
\hline 4.8 & $400 \times 260$ & & \multicolumn{1}{|}{} \\
\cline { 1 - 2 } 4 & $380 \times 250$ & \multicolumn{2}{|r}{} \\
\cline { 1 - 2 } & &
\end{tabular}

Table 2. The cross-sectional dimensions of the columns.

\begin{tabular}{|c|c|c|c|c|}
\hline \multirow{2}{*}{ Floor } & \multicolumn{2}{|c|}{$\begin{array}{c}\text { Interior Column } \\
\text { (Primary Building) }\end{array}$} & \multicolumn{2}{|c|}{$\begin{array}{c}\text { Exterior Column } \\
\text { (Secondary Building) }\end{array}$} \\
\hline & $\begin{array}{l}\text { Height } \\
\text { (m) }\end{array}$ & $\begin{array}{c}\text { Dimension } \\
(\mathrm{mm})\end{array}$ & $\begin{array}{l}\text { Height } \\
\text { (m) }\end{array}$ & $\begin{array}{c}\text { Dimension } \\
(\mathrm{mm})\end{array}$ \\
\hline $\begin{array}{c}\text { Base- } \\
\text { ment }\end{array}$ & 4.5 & $1400 \times 1400$ & 4.5 & $500 \times 500$ \\
\hline $1^{\text {st }}$ & 4.5 & $1400 \times 1400$ & 4.5 & $500 \times 500$ \\
\hline $2^{\text {nd }}$ & 4.5 & $1400 \times 1400$ & 4.5 & $500 \times 500$ \\
\hline $3^{\text {rd }}$ & 4.5 & $1400 \times 1400$ & 4.5 & $500 \times 500$ \\
\hline $4^{\text {th }}$ & 4.15 & $1200 \times 1200$ & \multicolumn{2}{|c|}{ Height Total $=18 \mathrm{~m}$} \\
\hline $5^{\text {th }}$ & 4.15 & $1200 \times 1200$ & & \\
\hline $6^{\text {th }}$ & 4 & $1000 \times 1000$ & & \\
\hline $7^{\text {th }}$ & 4 & $1000 \times 1000$ & & \\
\hline $8^{\text {th }}$ & 4 & $900 \times 900$ & & \\
\hline $9^{\text {th }}$ & 4 & $900 \times 900$ & & \\
\hline $10^{\text {th }}$ & 3.4 & $900 \times 900$ & & \\
\hline $11^{\text {st }}$ & 3.4 & $900 \times 900$ & & \\
\hline \multicolumn{3}{|c|}{ Height Total $=49.1 \mathrm{~m}$} & & \\
\hline
\end{tabular}

\subsubsection{The column}

Dimensions of columns were designed based on the SNI 2847:2013 requirements used for the buildings, as given in Table 2.

\subsubsection{The structural wall}

The dimensions of the building shear wall were designed with a thickness of $350 \mathrm{~mm}$ and the retaining wall with a thickness of $400 \mathrm{~mm}$.

\subsection{Modeling of the building structure}

In this research, two structural models of a 12-storied fixed base and base-isolated hotel buildings have been modeled and analyzed using structural analysis and design software package ETABS v.16. The fixed base building has been modeled with a fixed support at the base and the base-isolated building has been modeled incorporating rubber bearings near the base of the columns, as shown in Figs. 1 and 2, respectively. Those models included structural components such as RC columns, beams, shear walls for lift cores and slab. Other structural components were an overhead water tank and a helipad.

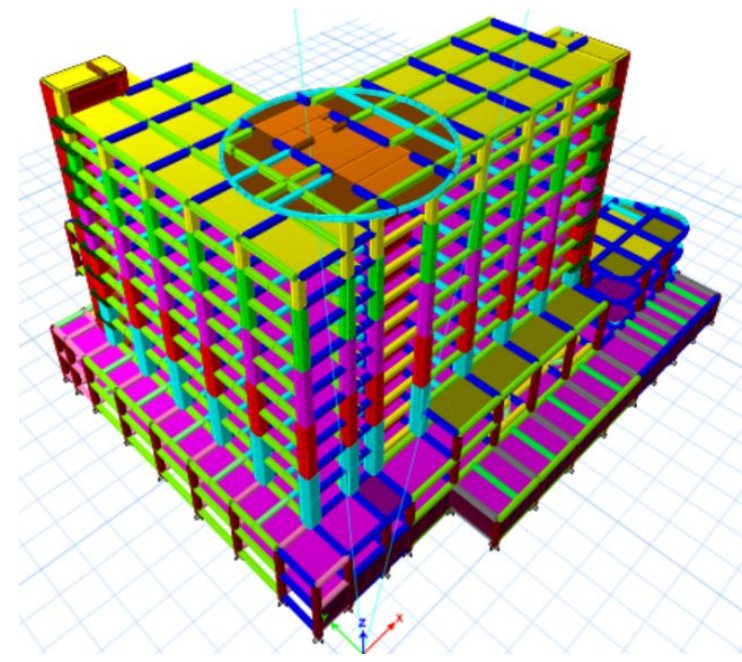

Fig. 1. The structural modeling of the building without the base isolator.

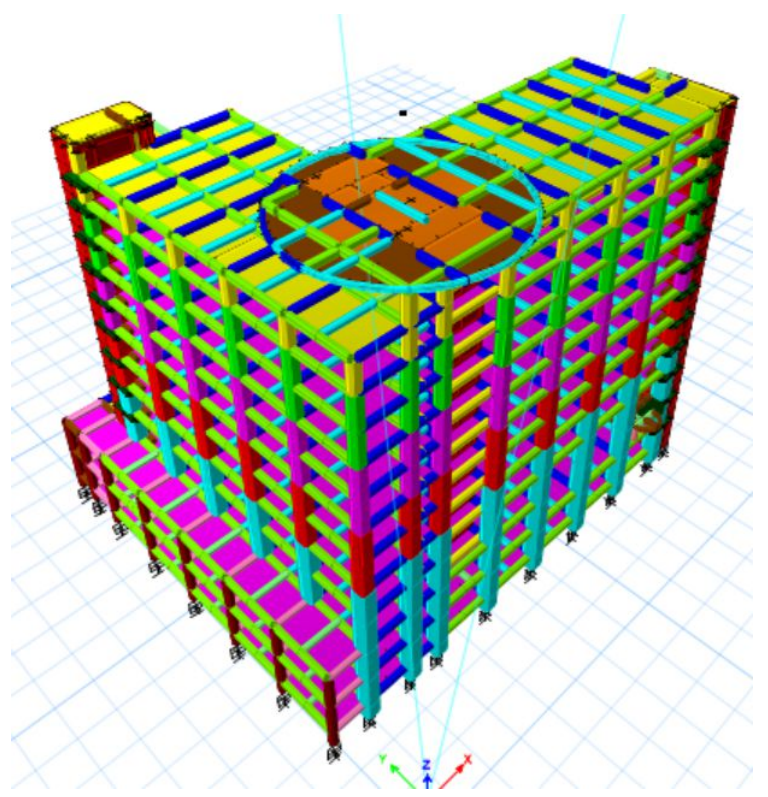

Fig. 2. The structural modeling of the building with the base isolator. 
There is separation on several parts of the baseisolated structure model building to obtain efficiency in the use of base isolators and to meet the requirements of SNI 1726-2012 article 12.2.5.2 [4]. All the procedures for preparing and applying base isolators can be seen in SNI 1726:2012 article 12. Some rules for modeling of base isolators can be explained in the following points.

\subsubsection{The examination room}

According to SNI 1726:2012 article 12.2.48, the base isolator must have its examination room to facilitate the maintenance and replacement of components in the occurrence of damage. In this building, an examination room is planned with a height of $2 \mathrm{~m}$ below the basement. The location of examination rooms and base isolators are shown in Fig. 3.

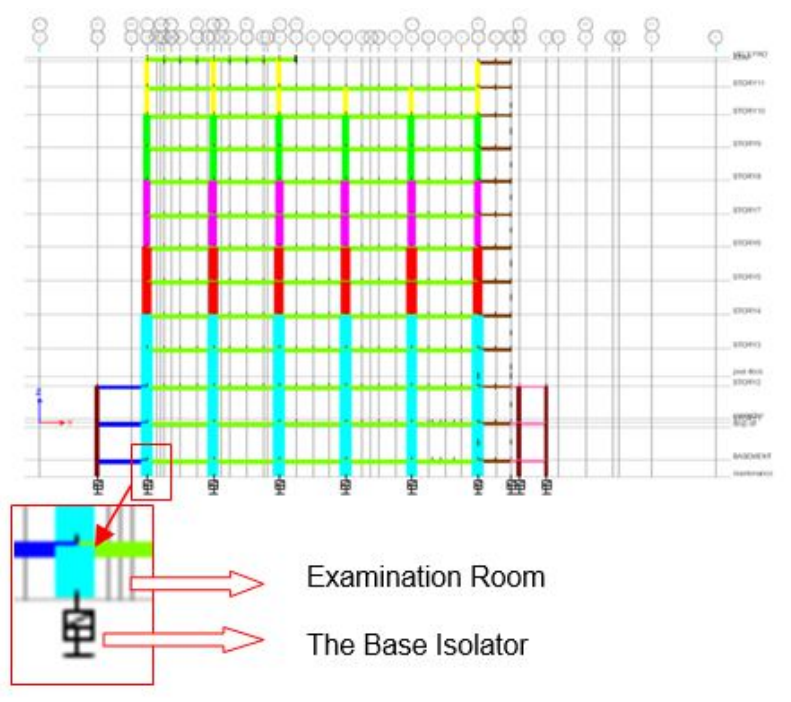

Fig. 3. The base isolator and its examination room modeling.

\subsubsection{The dimension of the base isolator}

A base-isolated structure is supported by a series of bearing pads which are placed between the building and the building's foundation. The base isolation system that was used in this building is the high damping rubber bearing (HDRB) with the classification MVBR-0430 (X0.6R). The specifications and characteristics of the base isolator are shown in Tables 3 and 4, respectively.

\subsection{Loads}

Loads are a primary consideration in any building design, which defines the nature and magnitude of hazards or external forces that a building must resist providing reasonable performance (i.e., safety and serviceability) throughout the structure's useful life [11].

\subsubsection{Dead load (D)}

Dead loads consist of the permanent construction material loads comprising the roof, floor, wall, and foundation systems, including claddings, finishes, and fixed equipment. The values for dead loads in Table 5 are for commonly used materials and constructions in residential buildings [12].

Table 3. The specification of HDRB.

\begin{tabular}{|c|c|c|c|c|c|}
\hline \multicolumn{2}{|c|}{ Properties } & Unit & $\begin{array}{c}\text { HH 060 } \\
\text { x 6R }\end{array}$ & $\begin{array}{c}\text { HH 070 } \\
\text { x 6R }\end{array}$ & $\begin{array}{c}\text { HH 080 } \\
\text { x 6R }\end{array}$ \\
\hline $\begin{array}{c}\text { Effective } \\
\text { outer } \\
\text { diameter }\end{array}$ & Do & $\mathrm{mm}$ & 600 & 700 & 800 \\
\hline $\begin{array}{c}\text { Shear } \\
\text { modulus }\end{array}$ & $\mathrm{G}$ & $\mathrm{N} / \mathrm{mm}^{2}$ & 0.62 & 0.62 & 0.62 \\
\hline $\begin{array}{c}\text { Thickness of } \\
\text { rubber layer }\end{array}$ & $\mathrm{tr}$ & $\mathrm{mm}$ & 4 & 4.7 & 5.4 \\
\hline $\begin{array}{c}\text { Number of } \\
\text { rubber layer }\end{array}$ & $\mathrm{n}$ & 50 & 43 & 37 \\
\hline $\begin{array}{c}\text { Total rubber } \\
\text { thickness }\end{array}$ & $\mathrm{Tr}$ & $\mathrm{mm}$ & 200 & 200 & 200 \\
\hline $\begin{array}{c}\text { First shape } \\
\text { factor }\end{array}$ & $\mathrm{S} 1$ & 36.6 & 36.4 & 36.1 \\
\hline $\begin{array}{c}\text { Second } \\
\text { shape factor }\end{array}$ & $\mathrm{S} 2$ & & 3 & 3.46 & 4 \\
\hline $\begin{array}{c}\text { Inner of lead } \\
\text { diameter }\end{array}$ & $\mathrm{di}$ & $\mathrm{mm}$ & 15 & 15 & 20 \\
\hline Height & $\mathrm{H}$ & $\mathrm{mm}$ & 407.9 & 388.3 & 422.2 \\
\hline Weight & $\mathrm{W}$ & $\mathrm{kN}$ & 6.5 & 7.9 & 11.9 \\
\hline Mass & $\mathrm{ton}$ & 0.66 & 0.8 & 1.21 \\
\hline
\end{tabular}

Table 4. The design characteristic of HDRB.

\begin{tabular}{|c|c|c|c|c|c|}
\hline \multicolumn{2}{|c|}{ Properties } & Unit & $\begin{array}{c}\text { HH 060 } \\
\text { x 6R }\end{array}$ & $\begin{array}{c}\text { HH 070 } \\
\mathbf{x} 6 R\end{array}$ & $\begin{array}{c}\text { HH 080 } \\
\text { x 6R }\end{array}$ \\
\hline $\begin{array}{c}\text { Normal } \\
\text { stress }\end{array}$ & $\sigma_{\mathrm{s}}$ & $\mathrm{N} / \mathrm{mm}^{2}$ & 6.6 & 9.1 & 12 \\
\hline $\begin{array}{c}\text { Shear } \\
\text { stiffness }\end{array}$ & $\mathrm{Kh}$ & $\begin{array}{c}.10^{3} \mathrm{kN} \\
/ \mathrm{m}\end{array}$ & 0.876 & 1.18 & 1.56 \\
\hline $\begin{array}{c}\text { Initial shear } \\
\text { stiffness }\end{array}$ & & $\begin{array}{c}.10^{3} \mathrm{kN} \\
/ \mathrm{m}\end{array}$ & 5.19 & 6.99 & 9.23 \\
\hline $\begin{array}{c}\text { Eff Damping } \\
\text { Ratio }\end{array}$ & & 0.24 & 0.24 & 0.24 \\
\hline $\begin{array}{c}\text { Ult. comp. } \\
\text { stress }\end{array}$ & $\sigma_{\mathrm{c}}$ & $\mathrm{N} / \mathrm{mm}^{2}$ & 7.4 & 1.6 & 4.11 \\
\hline $\begin{array}{c}\text { Ult. tensile } \\
\text { stress }\end{array}$ & $\sigma_{\mathrm{tu}}$ & $\mathrm{N} / \mathrm{m}^{2}$ & 1 & 1 & 1 \\
\hline $\begin{array}{c}\text { Compressive } \\
\text { stiffness }\end{array}$ & $\mathrm{Kv}$ & $.10^{3} \mathrm{kN}$ & 1970 & 2660 & 3510 \\
\hline $\begin{array}{c}\text { Strength of } \\
\text { yield }\end{array}$ & $\mathrm{KN}$ & $\mathrm{m}$ & 71.5 & 97.3 & 127 \\
\hline $\begin{array}{c}\text { Ult. } \\
\text { displacement }\end{array}$ & $\mathrm{d} / 2$ & $\mathrm{~mm}$ & 300 & 350 & 400 \\
\hline
\end{tabular}

\subsubsection{Earthquake load (E)}

Earthquake forces experienced by a building result from ground motions (accelerations) which are also fluctuating or dynamic they reverse direction somewhat 
chaotically [13]. Earthquake load is assumed as a vibration that gives cyclic load on buildings horizontally and vertically. As for this design, the earthquake acceleration in Padang was taken from the 2017 earthquake map with the parameters of the earthquake spectral response shown in Table 6.

Table 5. Additional dead load.

\begin{tabular}{|c|c|c|c|}
\hline No. & Type of load & Weight & Unit \\
\hline 1 & Steel & 78,5 & $\mathrm{kN} / \mathrm{m}^{3}$ \\
\hline 2 & Concrete & 22 & $\mathrm{kN} / \mathrm{m}^{3}$ \\
\hline 3 & River Stone & 22 & $\mathrm{kN} / \mathrm{m}^{3}$ \\
\hline 4 & Mortar & 22 & $\mathrm{kN} / \mathrm{m}^{3}$ \\
\hline 5 & Reinforced Concrete & 24 & $\mathrm{kN} / \mathrm{m}^{3}$ \\
\hline 6 & Sand & 16 & $\mathrm{kN} / \mathrm{m}^{3}$ \\
\hline 7 & Asphalt Coating & 14 & $\mathrm{kN} / \mathrm{m}^{2}$ \\
\hline 8 & Water & 10 & $\mathrm{kN} / \mathrm{m}^{2}$ \\
\hline 9 & Stonemasonry wall $1 / 2$ pair & 2,5 & $\mathrm{kN} / \mathrm{m}^{2}$ \\
\hline 10 & Curtain Wall + frame & 0,6 & $\mathrm{kN} / \mathrm{m}^{2}$ \\
\hline 11 & Ceiling and hanger & 0,2 & $\mathrm{kN} / \mathrm{m}^{2}$ \\
\hline 12 & Cladding metal sheet + frame & 0,2 & $\mathrm{kN} / \mathrm{m}^{2}$ \\
\hline 13 & Floor Finishing & 22 & $\mathrm{kN} / \mathrm{m}^{3}$ \\
\hline 14 & Marble, granite per $\mathrm{cm}$ thick & 0,24 & $\mathrm{kN} / \mathrm{m}^{2}$ \\
\hline 15 & Plumbing installation (ME) & 0,25 & $\mathrm{kN} / \mathrm{m}^{2}$ \\
\hline 16 & Tile roof coverings & 0,5 & $\mathrm{kN} / \mathrm{m}^{2}$ \\
\hline
\end{tabular}

From these data, the earthquake load can be simulated using spectrum response analysis and time history. Here, equivalent static analysis cannot be used because it does not meet the requirements of SNI 17262012 article 7.7.2. The analysis of time history is used because of the use of base isolators for SE site class.

\section{- Response spectrum analysis}

The response spectrum represents an envelope of upper bound responses, based on several different ground motion records. This method is an elastic dynamic analysis approach that relies on the assumption that dynamic response of the structure may be found by considering the independent response of each natural mode of vibration and then combining the response of each in the same way [14]. The spectrum dynamic response seismic loads based on SNI 1726:2012 are used in dynamic response analysis by adjusting the site classification and seismicity level in Padang City, as shown in Fig. 4.

\section{- Time history analysis}

Seismic loads are also generated in a structure by imposing ground accelerations. Dynamic time history analysis has been carried out on two buildings. Analysis procedures are available to compute the response of a structure to this type of load. In this study, the time versus ground acceleration graph of the Padang City earthquake, 2009 shown in Figs. 5 and 6, was used for the time history analysis.

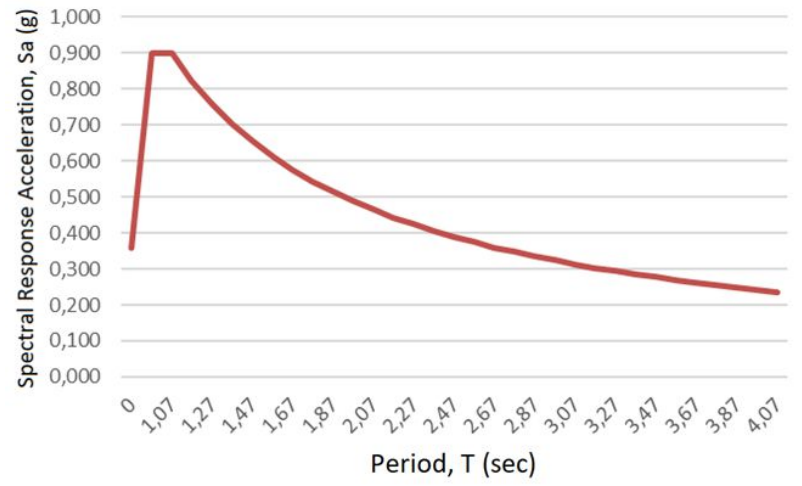

Fig. 4. The acceleration response spectrum of Padang City for soft soil.

Table 6. The earthquake load parameters.

\begin{tabular}{|c|c|c|c|}
\hline $\begin{array}{c}\text { Parameter } \\
\text { (SNI 1726:2012) }\end{array}$ & $\begin{array}{c}\text { Varia } \\
\text { ble }\end{array}$ & Value & $\begin{array}{l}\text { Info/ } \\
\text { Unit }\end{array}$ \\
\hline Risk category & & III & \\
\hline Importance factor & $\mathrm{I}_{\mathrm{e}}$ & 1 & \\
\hline \multirow{3}{*}{$\begin{array}{l}\text { The spectral response } \\
\text { acceleration values }\end{array}$} & Ss & 1.5 & $\mathrm{~g}$ \\
\hline & $\mathrm{S}_{1}$ & 0.6 & $\mathrm{~g}$ \\
\hline & PGA & 0.6 & $\mathrm{~g}$ \\
\hline \multirow{2}{*}{$\begin{array}{c}\text { Soil site class } \\
\text { (Standard Penetration Test } \\
\text { value } \mathrm{N} \text {, and shear wave } \\
\text { velocity } \mathrm{V}_{\mathrm{s}} \text { ) }\end{array}$} & N SPT & 7.71 & SE \\
\hline & $\mathrm{V}_{\mathrm{s}}$ & $\begin{array}{l}240 \\
227 \\
242\end{array}$ & SD \\
\hline \multirow{3}{*}{ Seismic amplification factors } & $\mathrm{F}_{\mathrm{a}}$ & 1.35 & $\mathrm{~g}$ \\
\hline & $\mathrm{F}_{\mathrm{v}}$ & 1.44 & $\mathrm{~g}$ \\
\hline & $\mathrm{F}_{\mathrm{PGA}}$ & 0.54 & $\mathrm{~g}$ \\
\hline \multirow{3}{*}{$\begin{array}{c}\text { The spectral response } \\
\text { acceleration parameters } \\
\text { corresponding to the soil site } \\
\text { class }\end{array}$} & $\mathrm{S}_{\mathrm{MS}}$ & 1.35 & $\mathrm{~g}$ \\
\hline & $\mathrm{S}_{\mathrm{M} 1}$ & 1.44 & $\mathrm{~g}$ \\
\hline & $\mathrm{PGA}_{\mathrm{m}}$ & 0.54 & g \\
\hline \multirow{2}{*}{$\begin{array}{l}\text { The value of the design } \\
\text { spectral response acceleration } \\
\text { at short periods and at a 1- } \\
\text { second period }\end{array}$} & $\mathrm{S}_{\mathrm{DS}}$ & 0.90 & $\mathrm{~g}$ \\
\hline & $\mathrm{S}_{\mathrm{D} 1}$ & 0.96 & $\mathrm{~g}$ \\
\hline Seismic design category & KDS & $\mathrm{D}$ & \\
\hline \multirow{7}{*}{ Fundamental period } & $\mathrm{T}_{0}$ & 0.21 & $\mathrm{sec}$ \\
\hline & $\mathrm{T}_{\mathrm{S}}$ & 1.07 & $\mathrm{sec}$ \\
\hline & $\mathrm{C}_{\mathrm{u}}$ & 1.40 & \\
\hline & $\mathrm{C}_{\mathrm{t}}$ & 0.0466 & \\
\hline & $\mathrm{X}$ & 0.90 & \\
\hline & $\mathrm{h}_{\mathrm{n}}$ & 44.10 & $\mathrm{~m}$ \\
\hline & $\mathrm{T}_{\mathrm{a}}$ & 1.41 & $\mathrm{sec}$ \\
\hline \multirow{3}{*}{$\begin{array}{l}\text { Seismic Response Factor, } \\
\text { Representative seismic } \\
\text { reduction factor of the building } \\
\text { structure (Dual system, shear } \\
\text { wall with SRMF) }\end{array}$} & $\mathrm{R}$ & 7 & \\
\hline & $\Omega$ & 2.5 & \\
\hline & $\mathrm{C}_{\mathrm{d}}$ & 5.5 & \\
\hline
\end{tabular}




\section{- Wind load (W)}

For buildings that have a height of more than 9 meters, the wind load should be simulated on the building. As for the International Melia Hotel with a height of 44.1 meters, wind load analysis was carried out using the Main Wind Load Retaining System with the following wind load parameter data:
a) Building risk categories
$=$ III
b) Basic Wind Speed of Padang
$=26 \mathrm{~km} / \mathrm{h}$
c) Wind Direction Factor, $K_{d}$
$=0.85$
d) Surface Roughness
e) Exposure Category
f) Topographic Factors, $K_{z t}$
$=\mathrm{C}$
$=\mathrm{C}$
$=1$
$=$ semi
$=0.55$
$=0.85$
i) Wind effect factors
$=1.37$
j) Exposure coefficient of velocity pressure $\mathrm{k}_{\mathrm{h}}$ and $\mathrm{k}_{\mathrm{z}}$
k) Velocity pressure, $q_{z}$
$=37.2 \mathrm{~N} / \mathrm{m}^{2}$

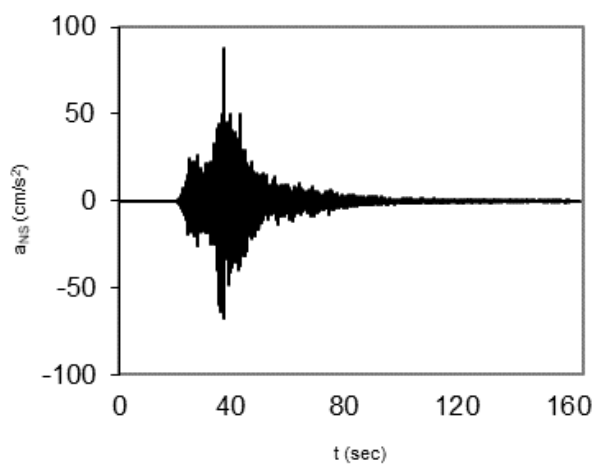

Fig. 5. Ground motion data for Padang Earthquake in 2009 (direction: north-south).

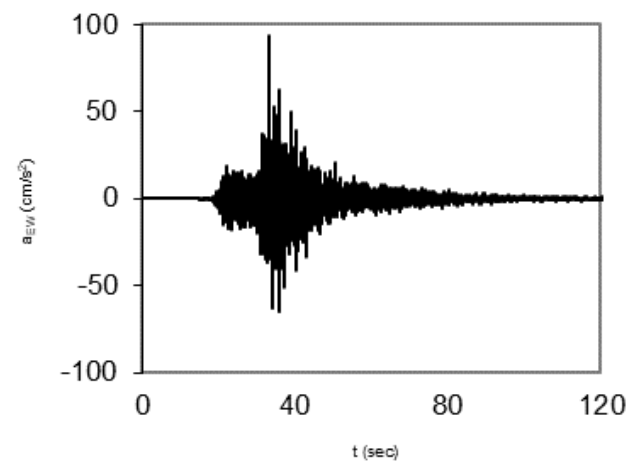

Fig. 6. Ground motion data for Padang Earthquake in 2009 (direction: east-west).

\section{Analysis results}

\subsection{Internal forces comparison}

This study demonstrated that the response was mainly affected by the incorporation of rubber bearings used as base isolators. To carry out a comparison between fixed base and base-isolated building by dynamic method on the bases of response properties like internal forces (axial, shear, and bending moment) in structural elements (beam and column), the point of view of internal force element is determined based on Fig. 7.

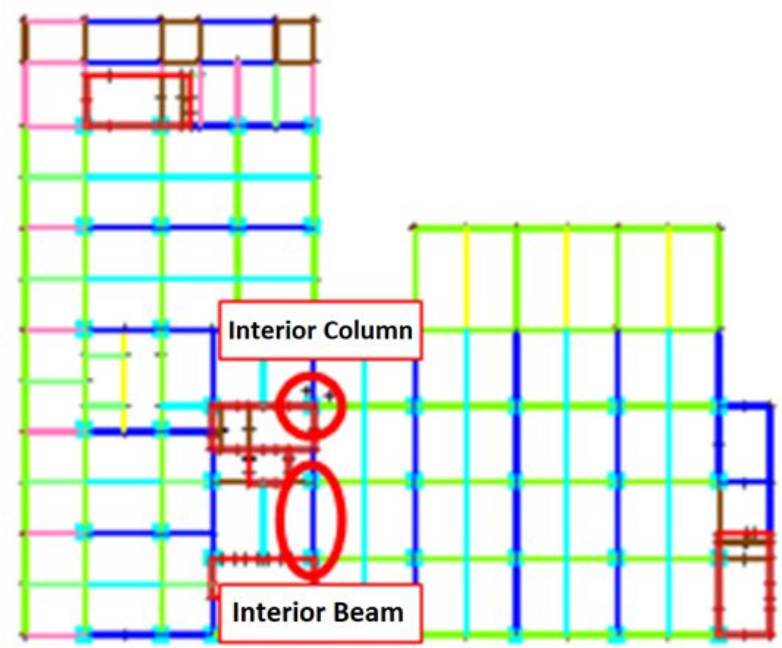

Fig. 7. The structural elements point of view.

\subsubsection{Interior beam}

The internal forces comparison on the fixed base and base-isolated buildings of the interior beam are shown in Tables 7 and 8 . Though while comparing the base of the structure, the base-isolated structure has the least value of internal forces and the percentage reduction is $14.09 \%$ and $24.76 \%$ for shear force and bending moment, respectively. However, there is an increase of internal forces in the ground floor due to the use of the base isolators. It is indicated that the structure on the ground floor must be more stiffness in the structural design.

Table 7. The comparison of beam shear forces for the fixed base and base-isolated buildings.

\begin{tabular}{|c|c|c|c|c|c|}
\hline \multirow{2}{*}{ Story } & \multirow{2}{*}{$\begin{array}{c}\text { Elev. } \\
\text { (m) }\end{array}$} & \multirow{2}{*}{$\begin{array}{c}\text { Span } \\
(\mathbf{m})\end{array}$} & \multicolumn{2}{|c|}{ Shear Force (kg) } & \multirow{2}{*}{$\begin{array}{l}\text { Reducti } \\
\text { on }(\%)\end{array}$} \\
\hline & & & Fixed & $\begin{array}{c}\text { Base } \\
\text { Isolator }\end{array}$ & \\
\hline Helypad & 44.1 & 6 & 4560 & 4684 & -2.71 \\
\hline 11 & 40.7 & 6 & 3754 & 3761 & -0.19 \\
\hline 10 & 37.3 & 6 & 2939 & 2082 & 29.17 \\
\hline 9 & 33.3 & 6 & 2988 & 2115 & 29.22 \\
\hline 8 & 29.3 & 6 & 3043 & 2180 & 28.38 \\
\hline 7 & 25.3 & 6 & 2984 & 2173 & 27.17 \\
\hline 6 & 21.3 & 6 & 3026 & 2263 & 25.23 \\
\hline 5 & 17.2 & 6 & 2864 & 2215 & 22.66 \\
\hline 4 & 13.1 & 6 & 2638 & 2175 & 17.56 \\
\hline 3 & 9 & 6 & 2329 & 2071 & 11.05 \\
\hline 2 & 4.5 & 6 & 3905 & 3911 & -0.16 \\
\hline 1 & 0 & 6 & 3924 & 3926 & -0.05 \\
\hline Basement & -4.5 & 6 & 3226 & 3357 & -4.06 \\
\hline
\end{tabular}


Table 8. The comparison of beam bending moment for the fixed base and base-isolated buildings.

\begin{tabular}{|c|c|c|c|c|c|}
\hline \multirow{2}{*}{ Story } & \multirow{2}{*}{$\begin{array}{c}\text { Elev. } \\
\text { (m) }\end{array}$} & \multirow{2}{*}{$\begin{array}{c}\text { Span } \\
\text { (m) }\end{array}$} & \multicolumn{2}{|c|}{$\begin{array}{c}\text { Bending } \\
\text { Moment (kgm) }\end{array}$} & \multirow{2}{*}{$\begin{array}{l}\text { Reducti } \\
\text { on }(\%)\end{array}$} \\
\hline & & & Fixed & $\begin{array}{c}\text { Base } \\
\text { Isolator }\end{array}$ & \\
\hline Helypad & 44.1 & 6 & 9107 & 6107 & 32.94 \\
\hline 11 & 40.7 & 6 & 9249 & 6068 & 34.39 \\
\hline 10 & 37.3 & 6 & 6256 & 4035 & 35.50 \\
\hline 9 & 33.3 & 6 & 6371 & 4116 & 35.40 \\
\hline 8 & 29.3 & 6 & 6434 & 4241 & 34.07 \\
\hline 7 & 25.3 & 6 & 6242 & 4232 & 32.19 \\
\hline 6 & 21.3 & 6 & 6186 & 4413 & 28.66 \\
\hline 5 & 17.2 & 6 & 5749 & 4328 & 24.71 \\
\hline 4 & 13.1 & 6 & 5142 & 4255 & 17.24 \\
\hline 3 & 9 & 6 & 4434 & 4063 & 8.37 \\
\hline 2 & 4.5 & 6 & 4946 & 5496 & -11.11 \\
\hline 1 & 0 & 6 & 3086 & 4921 & -59.42 \\
\hline Basement & -4.5 & 6 & 1671 & 4220 & -152.44 \\
\hline
\end{tabular}

\subsubsection{Interior column}

The internal forces comparison on the fixed base and base-isolated buildings of the interior column are shown in Tables 9, 10, and 11.

Table 9. The comparison of column axial force for the fixed base and base-isolated buildings.

\begin{tabular}{|c|c|c|c|c|c|}
\hline \multirow{2}{*}{ Story } & \multirow{2}{*}{$\begin{array}{c}\text { Elev. } \\
(\mathrm{m})\end{array}$} & \multirow{2}{*}{$\begin{array}{c}\text { Heig } \\
\text { ht } \\
\text { (m) }\end{array}$} & \multicolumn{2}{|c|}{ Axial Force (kg) } & \multirow{2}{*}{$\begin{array}{l}\text { Reduct } \\
\text { on }(\%)\end{array}$} \\
\hline & & & Fixed & $\begin{array}{c}\text { Base } \\
\text { Isolator }\end{array}$ & \\
\hline Helypad & 44.1 & 3.4 & 2862 & 1745 & 39.04 \\
\hline Roof & 43.7 & 3 & 7512 & 4612 & 38.60 \\
\hline 11 & 40.7 & 3.4 & 16457 & 5202 & 68.39 \\
\hline 10 & 37.3 & 4 & 55774 & 6517 & 88.32 \\
\hline 9 & 33.3 & 4 & 116359 & 11156 & 90.41 \\
\hline 8 & 29.3 & 4 & 203462 & 32240 & 84.15 \\
\hline 7 & 25.3 & 4 & 298527 & 62913 & 78.93 \\
\hline 6 & 21.3 & 4.1 & 465455 & 112506 & 75.83 \\
\hline 5 & 17.2 & 4.1 & 622754 & 168277 & 72.98 \\
\hline 4 & 13.1 & 4.1 & 840695 & 249413 & 70.33 \\
\hline 3 & 9 & 4.5 & 1003013 & 324674 & 67.63 \\
\hline 2 & 4.5 & 4.5 & 1149690 & 404947 & 64.78 \\
\hline 1 & 0 & 4.5 & 1234356 & 485381 & 60.68 \\
\hline Basement & -4.5 & 2 & 1232161 & 559221 & 54.61 \\
\hline
\end{tabular}

Table 10. The comparison of column shear forces for the fixed base and base-isolated buildings.

\begin{tabular}{|c|c|c|c|c|c|}
\hline \multirow{2}{*}{ Story } & \multirow{2}{*}{$\begin{array}{c}\text { Elev. } \\
\text { (m) }\end{array}$} & \multirow{2}{*}{$\begin{array}{c}\text { Heig } \\
\text { ht } \\
\text { (m) }\end{array}$} & \multicolumn{2}{|c|}{ Shear Force (kg) } & \multirow{2}{*}{$\begin{array}{l}\text { Reducti } \\
\text { on (\%) }\end{array}$} \\
\hline & & & Fixed & $\begin{array}{c}\text { Base } \\
\text { Isolator }\end{array}$ & \\
\hline Helypad & 44.1 & 3.4 & 4141 & 2569 & 37.94 \\
\hline Roof & 43.7 & 3 & 4272 & 1901 & 55.49 \\
\hline 11 & 40.7 & 3.4 & 2650 & 657 & 75.18 \\
\hline 10 & 37.3 & 4 & 5801 & 1403 & 75.81 \\
\hline 9 & 33.3 & 4 & 7499 & 1754 & 76.60 \\
\hline 8 & 29.3 & 4 & 10255 & 2400 & 76.59 \\
\hline 7 & 25.3 & 4 & 12475 & 2719 & 78.20 \\
\hline 6 & 21.3 & 4.1 & 19046 & 4138 & 78.27 \\
\hline 5 & 17.2 & 4.1 & 22116 & 5037 & 77.22 \\
\hline 4 & 13.1 & 4.1 & 32351 & 7898 & 75.58 \\
\hline 3 & 9 & 4.5 & 33394 & 8470 & 74.64 \\
\hline 2 & 4.5 & 4.5 & 43014 & 9664 & 77.53 \\
\hline 1 & 0 & 4.5 & 23703 & 10703 & 54.84 \\
\hline Basement & -4.5 & 2 & 49426 & 11714 & 76.30 \\
\hline
\end{tabular}

Table 11. The comparison of column bending moment for the fixed base and base-isolated buildings.

\begin{tabular}{|c|c|c|c|c|c|}
\hline \multirow{2}{*}{ Story } & \multirow{2}{*}{$\begin{array}{l}\text { Elev. } \\
\text { (m) }\end{array}$} & \multirow{2}{*}{$\begin{array}{c}\text { Heig } \\
\text { ht } \\
\text { (m) }\end{array}$} & \multicolumn{2}{|c|}{$\begin{array}{l}\text { Bending Moment } \\
\text { (kgm) }\end{array}$} & \multirow{2}{*}{$\begin{array}{l}\text { Reducti } \\
\text { on }(\%)\end{array}$} \\
\hline & & & Fixed & $\begin{array}{l}\text { Base } \\
\text { Isolator }\end{array}$ & \\
\hline Helypad & 44.1 & 3.4 & 2536 & 2603 & -2.66 \\
\hline Roof & 43.7 & 3 & 4351 & 2779 & 36.13 \\
\hline 11 & 40.7 & 3.4 & 2295 & 851 & 62.88 \\
\hline 10 & 37.3 & 4 & 5090 & 2066 & 59.41 \\
\hline 9 & 33.3 & 4 & 7584 & 2139 & 71.79 \\
\hline 8 & 29.3 & 4 & 12282 & 2667 & 78.28 \\
\hline 7 & 25.3 & 4 & 16390 & 3044 & 81.42 \\
\hline 6 & 21.3 & 4.1 & 28856 & 5573 & 80.69 \\
\hline 5 & 17.2 & 4.1 & 37082 & 7380 & 80.10 \\
\hline 4 & 13.1 & 4.1 & 54938 & 11399 & 79.25 \\
\hline 3 & 9 & 4.5 & 68746 & 14901 & 78.32 \\
\hline 2 & 4.5 & 4.5 & 97556 & 17737 & 81.82 \\
\hline 1 & 0 & 4.5 & 75756 & 21316 & 71.86 \\
\hline Basement & -4.5 & 2 & 51255 & 14466 & 71.78 \\
\hline
\end{tabular}

When comparing the fixed base and base-isolated structures, the percentage reductions of internal forces for base-isolated structures are $68.19 \%, 70.72 \%$, and $71.82 \%$ for axial, shear forces, and bending moment, respectively. But on the helipad floor, there is an increase in bending moment. It is indicated by the large stiffness in the short column of the helipad. 


\subsection{The comparison of displacement and inter- story drift}

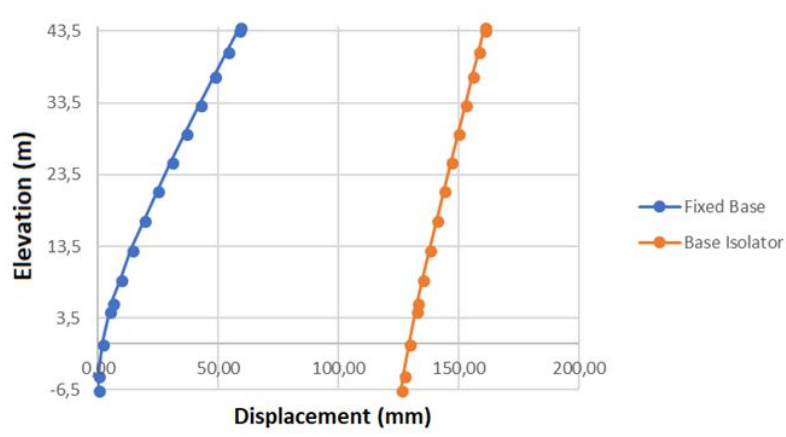

Fig. 8. The comparison of displacement for the fixed base and base-isolated buildings in the $\mathrm{X}$ direction.

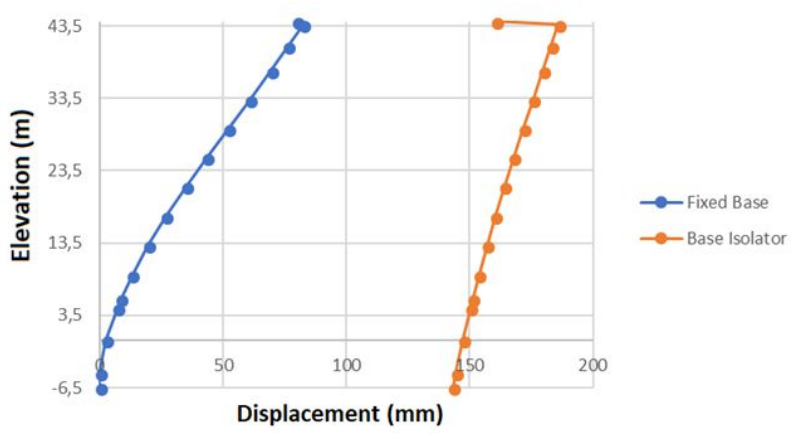

Fig. 9. The comparison of displacement for the fixed base and base-isolated buildings in the $\mathrm{Y}$ direction.

Table 12. The comparison of inter-story drift for the fixed base and base-isolated buildings in the $\mathrm{X}$ direction.

\begin{tabular}{|c|c|c|c|c|c|c|}
\hline \multirow{2}{*}{ Story } & \multirow{2}{*}{$\begin{array}{c}\text { Elev. } \\
(\mathbf{m})\end{array}$} & \multicolumn{2}{|c|}{$\begin{array}{c}\text { Displacement } \\
\text { (mm) }\end{array}$} & \multicolumn{2}{c|}{$\begin{array}{c}\text { Inter-story } \\
\text { Drift (mm) }\end{array}$} & \multirow{2}{*}{$\begin{array}{c}\text { Reduct } \\
\text { ion }\end{array}$} \\
\cline { 3 - 6 } & & Fixed & $\begin{array}{c}\text { Isolat } \\
\text { or }\end{array}$ & Fixed & $\begin{array}{c}\text { Isolat } \\
\text { or }\end{array}$ & \\
\hline Helypad & 44.1 & 58.9 & 160.5 & 0.6 & 0.28 & 52.18 \\
\hline Roof & 43.7 & 58.3 & 160.2 & 4.6 & 2.18 & 52.64 \\
\hline 11 & 40.7 & 53.7 & 158.0 & 5.3 & 2.51 & 52.86 \\
\hline 10 & 37.3 & 48.4 & 155.5 & 6.1 & 2.98 & 51.43 \\
\hline 9 & 33.3 & 42.2 & 152.6 & 5.9 & 3.00 & 49.41 \\
\hline 8 & 29.3 & 36.3 & 149.6 & 5.9 & 3.01 & 49.28 \\
\hline 7 & 25.3 & 30.4 & 146.5 & 5.7 & 3.00 & 47.90 \\
\hline 6 & 21.3 & 24.6 & 143.5 & 5.6 & 3.02 & 46.16 \\
\hline 5 & 17.2 & 19.0 & 140.5 & 5.2 & 2.94 & 43.75 \\
\hline 4 & 13.1 & 13.8 & 137.6 & 4.4 & 2.82 & 36.49 \\
\hline 3 & 9 & 9.4 & 134.8 & 3.7 & 2.17 & 40.72 \\
\hline $\begin{array}{c}\text { Pool } \\
\text { deck }\end{array}$ & 5.7 & 5.7 & 132.6 & 1.0 & 0.75 & 24.30 \\
\hline 2 & 4.5 & 4.7 & 131.8 & 2.9 & 2.67 & 9.97 \\
\hline 1 & 0 & 1.7 & 129.2 & 1.7 & 2.35 & -35.61 \\
\hline $\begin{array}{c}\text { Base- } \\
\text { ment }\end{array}$ & -4.5 & 0.0 & 126.8 & 0.0 & 0.92 & -100.0 \\
\hline $\begin{array}{c}\text { Mainte- } \\
\text { nance }\end{array}$ & -6.5 & 0.0 & 125.9 & & & \\
\hline
\end{tabular}

Table 13. The comparison of inter-story drift for the fixed base and base-isolated buildings in the $\mathrm{Y}$ direction.

\begin{tabular}{|c|c|c|c|c|c|c|}
\hline \multirow{2}{*}{ Story } & \multirow{2}{*}{$\begin{array}{c}\text { Elev. } \\
(\mathbf{m})\end{array}$} & \multicolumn{2}{|c|}{$\begin{array}{c}\text { Displacement } \\
\text { (mm) }\end{array}$} & \multicolumn{2}{|c|}{$\begin{array}{c}\text { Inter-story } \\
\text { Drift (mm) }\end{array}$} & \multirow{2}{*}{$\begin{array}{c}\text { Reduct } \\
\text { ion } \\
\text { (\%) }\end{array}$} \\
\cline { 3 - 6 } & & Fixed & $\begin{array}{c}\text { Isolat } \\
\text { or }\end{array}$ & Fixed & $\begin{array}{c}\text { Isolat } \\
\text { or }\end{array}$ & \\
\hline Helypad & 44.1 & 80.1 & 160.8 & -2.46 & -25.04 & -916.7 \\
\hline Roof & 43.7 & 82.5 & 185.8 & 6.14 & 2.89 & 52.96 \\
\hline 11 & 40.7 & 76.4 & 182.9 & 7.07 & 3.31 & 53.11 \\
\hline 10 & 37.3 & 69.3 & 179.6 & 8.49 & 3.94 & 53.66 \\
\hline 9 & 33.3 & 60.8 & 175.5 & 8.67 & 3.98 & 54.04 \\
\hline 8 & 29.3 & 52.2 & 171.7 & 8.67 & 3.91 & 54.90 \\
\hline 7 & 25.3 & 43.5 & 167.8 & 8.50 & 3.69 & 56.53 \\
\hline 6 & 21.3 & 34.9 & 164.1 & 8.20 & 3.75 & 54.27 \\
\hline 5 & 17.2 & 26.8 & 160.4 & 7.25 & 3.44 & 52.54 \\
\hline 4 & 13.1 & 19.5 & 156.9 & 6.52 & 3.21 & 50.77 \\
\hline 3 & 9 & 13.0 & 153.7 & 4.63 & 2.50 & 46.06 \\
\hline $\begin{array}{c}\text { Pool } \\
\text { deck }\end{array}$ & 5.7 & 8.4 & 151.2 & 1.17 & 0.88 & 25.06 \\
\hline 2 & 4.5 & 7.2 & 150.3 & 4.80 & 3.14 & 34.54 \\
\hline 1 & 0 & 2.4 & 147.2 & 2.42 & 2.79 & -15.64 \\
\hline $\begin{array}{c}\text { Base- } \\
\text { ment }\end{array}$ & -4.5 & 0.0 & 144.4 & 0.00 & 1.11 & -100.0 \\
\hline $\begin{array}{c}\text { Mainte- } \\
\text { nance }\end{array}$ & -6.5 & 0.0 & 143.3 & & & \\
\hline & & & & & \\
\hline
\end{tabular}

Story displacements are plotted graphically in Figs. 8 and 9. Displacement of the structure building subjected to time history analysis is recorded in each node in both $\mathrm{X}$ and $\mathrm{Y}$ directions. There is no displacement is recorded at the base since the base is in the fixed condition. The reduction of inter-story drift between fixed base and base isolator building for $\mathrm{X}$ and $\mathrm{Y}$ directions are shown in Tables 12 and 13, respectively. The use of HDRB base isolator reduces the inter-story drift by around $56.53 \%$, but, there is an increase in deviation on the helipad since the large stiffness in their short columns.

\section{Conclusions}

Dynamic Response Spectrum and Time History Analysis are carried out for the Melia International Hotel building. The building is modeled and analyzed using fixed base and base-isolated structures. The comparison of structure responses between fixed and base-isolated building structures like internal forces in structural elements, story displacement, and inter-story drift has been done. The results of the analysis can be summarized as follow:

1. The maximum reduction in beam's internal forces of shear force and bending moment is $29.22 \%$ and $35.50 \%$, respectively when isolated with HDRB as compared to the fixed base condition. Also, the column's internal forces of base-isolated structures reduced by average $68.19 \%$ for axial, $70.72 \%$ for shear, and $71.82 \%$ for bending moment compared to the fixed base structure. 
2. On the ground floor, there is an increase in the beam's internal forces due to the use of the base isolators. It is indicated that the structure of the ground floor must be given more stiffness. Also, on the helipad floor, there is an increase in the column's internal force due to the large stiffness in the short column of the helipad.

3. There is no displacement recorded at the base since the base is in the fixed condition. There is a $56.53 \%$ reduction in an inter-story drift on the base-isolated structure compared to the fixed-base structure.

4. From this study, it was proved that the performance of the base-isolated building is much better compared to the fixed base building. So, it is recommended to use the HDRB base isolation for medium and high rise buildings in Padang City, Indonesia, especially in soft soil conditions.

The authors would like to thank the Engineering Faculty of Andalas University for financial support in publishing this article (grant number 028/UN.16.09.D/PL/2019).

\section{References}

1. Fauzan, Apriwelni S., and Rizki A., Proc. of $A C E$ Conf. 3 (15) 267-274 (2016)

2. Febrin A.I., J. R. S. 1, (8) (2012)

3. Muharam A.F., Modification of Surabaya One East Residance Apartment Structure Design with Composite Structure and Base Isolator: High
Dumping Rubber Bearing, Surabaya, Sepuluh November Ins. of Tech. (2017)

4. SNI 03-1726-2012, Earthquake Resilience Design Procedures for Building and Non-Building, Jakarta, National Standardization Agency (2012)

5. Lakshmi G.S., Prasad S.S.V., Venkateswarlu D., Int. $\mathrm{J}$ for Modern Trends in Science and Tech. 3(6) (2017)

6. Ghodke R.B., Admane S.V., Int. J of Sc, Eng. and Tech.Research 4 (4) (2015)

7. Talikoti R.S., Thorat V.R., Int. J. of Eng. Research \& Tech. 3 (7) (2014)

8. National Standardization Agency, SNI 1726-2012 Design Method of Earthquake Resistance for Buildings and Other Structures, BSN, Jakarta (2012)

9. Tolani S., Sharma A., American J. of Eng. Research 5 (5) 198-209

10. National Standardization Agency, SNI 2847: 2013 Requirements of Concrete Structure for Building, BSN, Jakarta (2013)

11. National Standardization Agency, SNI 1727: 2013 Minimum Load for The Design Of Buildings and Other Structures (in Indonesia), BSN, Jakarta (2013)

12. Khannavar S., Kolhar M.H., Int. Research J. of Eng. and Tech. 3 (7) (2016)

13. Tafheem Z., Arafat T.A., Chowdhury A., and Iqbal A., J. of Civil Eng., Science and Tech. 8 (1) (2017)

14. Patel Y., Pandey P.K., Int. J. of Adv. Eng. and Research Development 4 (4) (2017) 